\title{
Cigarette, A Child!
}

\section{Sigara, Bir Evlat!}

\author{
Onur Öztürk*1
}

\section{ÖZET}

Yalnızlık, kişiyi çözüm yolları aramaya iter. Sigara, maalesef içicilere sorulduğunda yalnızlıkla başa çıkma yollarından biri olarak görülmektedir. Çocuğu olmayan yaşlı bir hastamız sigarayı kendi evladı yerine koymaktadır. Bu yüzden sigarayı bırakmayı henüz düşünmemektedir. Dirençli vakalarda önce sigara bağımlılığının etyolojisi saptanmalı, sonra psikoterapi desteği sağlanmalıdır.

Anahtar kelimeler: Evlat, sigara kullanma, yalnızlık

\section{ABSTRACT}

Loneliness pushes the person to seek solutions. When smokers are asked, unfortunately cigarette smoking is regarded as a way to cope with loneliness. An elderly male patient without children regarded cigarette as his own child. Therefore, he could not even think of quitting smoking. In resisting cases, firstly the etiology of smoking addiction should be determined, then psychotherapeutic support should be provided.

Key words: Child, cigarette smoking, loneliness

Received / Geliş tarihi: 30.12.2016, Accepted / Kabul tarihi: 17.02.2017

${ }^{1}$ Samsun Asarcik Family Healthcare Center

*Address for Correspondence / Yazışma Adresi: Onur Öztürk, Asarcik Family Healthcare Center, Samsun-Turkey, E-mail: dr.onurozturk@yahoo.com

Öztürk O. Cigarette, A Child!, TJFMPC, 2017;11(1): 1-3.

DOI: $10.21763 /$ tjfmpc. 295607 


\section{Dear Editor,}

Loneliness is defined as an undesired and unpleasant experience, which is mostly evaded and accompanied with anxiety, anger, sadness and the feeling of being different from other people. ${ }^{1}$ This experience causes people to look for an escape from the feeling of isolation from life and to react. ${ }^{2}$ The person may find the escape in various ways and cigarette smoking is one of them. Several studies have reported a significant correlation between cigarette smoking and loneliness. ${ }^{3,4}$ It should be kept in mind that this relationship could also be vice versa. ${ }^{5}$ The use of smoking for self-medication is especially emphasized in the literature.

A 76-year-old male patient applied to our family health center and requested painkillers and vitamin medication in December 2016. The patient, a retired worker and married for 58 years, had no children. That was his first application to the clinic for the last two years. In his medical history, the patient said that his general health status is quite good and he rarely goes to the hospital. Because of the intense cigarette smoke odor, he was immediately inquired about whether he smokes or not. The patient said that he smokes since he was siz years old (for 70 years). He initially smoked a few cigarettes/day when he was young. He increased to three boxes/year during his military duty. Then, he continued to smoke 2-3 boxes/day and now he smokes 10-12 cigarettes/day since the last one year. He was rolling his own cigarettes. He said 'I can not speak everything with my wife. I am feeling very lonely. I regard cigarette as my child. I am seeking refuge in cigarette when I feel alone. I do not want to quit smoking. I do not believe I can quit'.

In detailed medical history, he did not mention any complaints except for occasional indigestion and knee pain. He was neither diagnosed with a chronic disease nor using a longterm medication. His wife was a 74-year-old healthy non-smoker. His family history was noncontributory. The score of the Fagerstrom nicotine dependence test (FNDT) of the patient was determined as 8/10. Besides, University of California, Los Angeles Loneliness Scale (UCLALS) score was $57 / 80$.

The FNDT and UCLA-LS scores of the patient were high. These test scores showed that the patient feels lonely and has a high level of smoking addiction, which confirmed the medical history. The relationship between loneliness and smoking in certain cohorts who often feel lonely has been studied in the literature. As loneliness increased, smoking was observed to increase. ${ }^{6}$ Mayda et al. observed that the reason for starting smoking was loneliness in $20.6 \%$ of college students and students living alone were smoking more cigarettes. ${ }^{7}$ Moreover, Seyfikli et al. showed that the reasons for starting smoking were associated with loneliness in $17.6 \%$ of housewives. ${ }^{8}$ In another study conducted on Indian workers laboring in Arabia, it was observed that loneliness is an important risk factor for cigarette smoking among these immigrant workers. ${ }^{9} \quad$ Similarly, a study conducted on adolescents living in orphanage showed that the prevalence of smoking reached almost $50 \%$, while feeling of loneliness was higher in smoking adolescents compared to non-smokers. ${ }^{10}$ Chou and Chi showed that the feeling of loneliness is significantly high in elderly people without children. ${ }^{11}$

It was asserted by smokers that cigarette confronts loneliness by several mechanisms. Having a role as a pharmaceutical agent ${ }^{12}$ and being a socialising tool ${ }^{13}$ are the most stated ones among these mechanisms. To regard the cigarette as a replacement for a child may intensify the addiction and therefore may cause resistance to smoking cessation. In such cases, firstly the etiology of smoking addiction should be determined, then psychotherapeutic support should be provided.

\section{REFERENCES}

1. Russell D, Peplau LA, Cutrona CE. The revised UCLA loneliness scale: concurrent and discriminant validity evidence. Journal of Personality and Social Psychology 1980;39(3):472-480.

2. Cacioppo JT, Cacioppo S, Boomsma DI. Evolutionary mechanisms for loneliness. Cognition and Emotion 2014;28(1):3-21.

3. Christopherson TM, Conner BT. Mediation of late adolescent health-risk behaviors and gender influences. Public Health Nursing 2012;29(6):510-524.

4. Laursen B, Hartl AC. Understanding loneliness during adolescence: developmental changes that increase the risk of perceived social isolation. Journal of Adolescence 2013;36(6):1261-1268.

5. DyalSR, ValenteTW.A systematic review of lonelinessand smoking: small effects, big implications. Subst Use Misuse 2015;50(13):1697-716.

6. Stickley A, Koyanagi A, Roberts B, Richardson E, Abbott P, Tumanov S, et al. Loneliness: its correlates and association with health behaviours and outcomes in nine countries of theformer Soviet Union. PLoS One 4 Jul 2013;8(7):e67978.

7. Mayda AS, Tufan N, Baştaş S. Düzce tıp fakültesi öğrencilerinin sigara konusundaki 
tutumları ve içme sıklıkları. Kor Hek 2007;6(5):364-370.

8. Seyfikli Z, Gönlügür U, Sümer H, Topçu S. Sivas'ta ev kadınlarında sigara alışkanlıkları. Tüberküloz ve Toraks Dergisi 2001;49(1):3740.

9. Ahmad MS. Prevalence and attitude of cigarette smoking among Indian expatriates living in Jeddah, Kingdom of Saudi Arabia. J Int Oral Health 2015;7(4):18-21.

10. Durualp E, Çiçekoğlu P. Yetiştirme yurduna kalan ergenlerin yalnızlık düzeylerinin internet bağımlılığı ve diğer değişkenler açısından incelenmesi. DEÜ SBE Dergisi 2013;15(1) 2946.

11. Chou KL, Chi I. Childlessness and psychological well-being in Chinese older adults. International Journal of Geriatric Psychiatry 2004;19(5):449-457.

12. Khantzian EJ. The self-medication hypothesis of addictive disorders: focus on heroin and cocaine dependence. The American Journal of Psychiatry 1985;142(11):1259-1264.

13. DeWall CN, Pond RS. Loneliness and smoking: the costs of the desire to reconnect. Self and Identity 2011;10(3):375-385. 